OBSERVATIONS

\title{
Martin McKee: "Never bloody here"
}

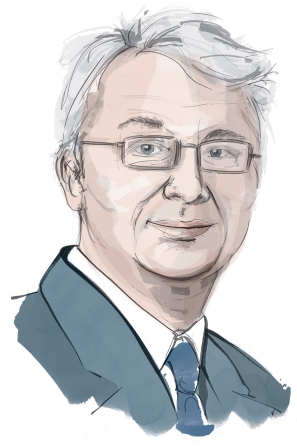

\section{What was your earliest ambition?}

From a very early age I was fascinated by foreign countries and was encouraged by my mother. I journeyed through Greece and the Balkans on Interrail when I was 15, and I haven't stopped travelling since.

\section{Who has been your biggest inspiration?}

Rudolf Virchow, an eminent pathologist. His investigation into the typhus outbreak in Silesia is a classic, identifying the power of the aristocracy as the fundamental cause. His modern equivalent is Salim Yusuf at McMaster University [in Ontario, Canada], an outstanding clinician who understands the need to tackle the fundamental determinants of health.

\section{What was the worst mistake in your career?}

A year spent in fruitless pursuit of a radioimmunoassay to measure an obscure peptide. I realised how junior researchers could be exploited.

\section{What was your best career move?}

After my MSc I accepted a registrar post split between Islington Health Authority and LSHTM. I had three incredibly supportive bosses: Leila Lessof, Patrick Hamilton, and Nick Black. They were all role models for me in their own way, and they opened many doors that set me on the journey to where I am today.
Bevan or Lansley? Who has been the best and the worst health secretary in your lifetime?

Bevan was a hero, but Attlee's government overall deserves some of the credit. The recent NHS reforms are a disaster, but the cabinet and parliament must share responsibility. MPs and peers failed abysmally in their duty by passing a law that few understood - and many of those who did so stood to profit from it.

\section{Who is the person you would most like to thank and why?}

My wife, for her endless support, sitting through boring speeches, running an unpaid bed and breakfast for visiting academics, and putting up with my long absences.

\section{To whom would you most like to apologise?}

My daughters, for missing so many important events in their lives because of my crazy travel schedule. Fortunately, they seem to have forgiven me.

\section{If you were given $£ 1 \mathrm{~m}$ what would you spend it on?}

I'd use a little for a trip around South America; incredibly, despite having visited over 120 countries I've never been there. I'd give the rest to Médecins Sans Frontières. I'm fortunate to know and to have been inspired by many of its current and former staff. It's been one of the few organisations to come out of the Ebola outbreak with its reputation enhanced.

\section{Where are or were you happiest?}

On a tropical beach or in the French Alps with my family.

\section{What single unheralded change has made the most difference in your field in your lifetime?}

The internet—and, with it, Skype, Twitter, PubMed, Wikipedia, and WhatsApp. I can remember the days of searching through paper copies of Index Medicus or of booking a phone call home from Belarus a week in advance. On the other hand, Twitter has 
Biography

Martin McKee is an inescapable presence to anybody with even a fleeting interest in public health. Prodigiously productive, he focuses his research on people affected by rapid political and economic change. His commentaries are infused with crusading zeal and a sense of social justice that brook no opposition. He grew up in Belfast, the son of GPs, and migrated in 1986 to the London School of Hygiene and Tropical Medicine (LSHTM), where he is now professor of European public health. If there's an advisory or editorial board that he's not a member of, somebody's slipped up.

provided a platform for some very unpleasant and disturbed people to attack anyone who stands up for public health.

\section{Do you support doctor assisted suicide?}

No. I've had the privilege to know some remarkable advocates of palliative care, such as Kathy Foley and Irene Higginson, and to realise what can be done to alleviate suffering.

\section{What book should every doctor read?}

Geoffrey Rose's Strategy of Preventive Medicine, which showed that the determinants of disease in individuals and populations differ-and so must the responses.

\section{What poem, song, or passage of prose would you like mourners at your funeral to hear?}

Beethoven's Ode to Joy. As a symbol of European unity it captures much of what I have worked for over three decades.

\section{What is your guiltiest pleasure?}

Schadenfreude (but highly selectively).

\section{If you could be invisible for a day what would you do?}

My Cochrane lecture looked at the replacement of empirical evidence by ideology in Soviet medicine. I suspect that the same may be true of our security services, but I can't exclude the possibility that they are under the influence of mind altering drugs. I'd love to research decision making by the UK's Joint Intelligence Committee to discover which of those is true.

\section{Clarkson or Clark? Would you rather watch Top Gear or Civilisation? What television programmes do you like?}

Given how much I am away I download lots of documentaries onto BBC iPlayer, but I never manage to watch them all. I do try to see every episode of University Challenge, if only to confirm that my grey cells haven't yet atrophied.

\section{What is your most treasured possession?}

A watch that my wife gave me on my 40th birthday.

\section{What, if anything, are you doing to reduce your carbon footprint?}

Skype, but no one who travels as much as I do uses it for fun.

\section{What personal ambition do you still have?}

To write a book on European cities, with each chapter on a different historical aspect of public health.

\section{Summarise your personality in three words}

My colleagues might say, "Out of office," but I'd like to think they would say tenacious, courageous (maybe foolhardy), and supportive. My wife says, "Never bloody here."

\section{Where does alcohol fit into your life?}

It's been a major research subject for two decades, especially in Russia. Otherwise, it depends entirely on where I am; however, I am partial to a mojito on a warm tropical evening or a glass of Tokay wine when visiting my Hungarian colleagues.

\section{What is your pet hate?}

Politicians who treat us like idiots, closely followed by sycophantic interviewers who fail to hold them to account.

\section{What would be on the menu for your last} supper?

If I'm going to die anyway, an Ulster fry with soda bread and black pudding.

\section{Do you have any regrets about becoming an academic?}

None. LSHTM, under a succession of inspirational directors, has been a fantastic place to work. Unusually, it has kept faith with the duty of a university to contribute to making the world a better place.

\section{If you weren't in your present position} what would you be doing instead?

Advocating more strongly for health and human rights in vulnerable populations. I chair the global health board for George Soros's Open Society Foundations in New York. The work that our staff do is simply amazing. 